\title{
THE COMPARISON OF ANTIOXIDATIVE PROPERTIES OF SEAWEED OLIGOSACCHARIDES FERMENTED BY TWO LACTIC ACID BACTERIA
}

Shao-Chi Wu

Department of Food Science and Technology, Tung-Fang Institute of Technology, Kaohsiung, Taiwan, R.O.C

Fu-Jin Wang

Department of Tourism, Aletheia University, Taipei, Taiwan, R.O.C.

Chorng-Liang Pan

Department of Food Science, National Taiwan Ocean University, Keelung, Taiwan, R.O.C, b0037@mail.ntou.edu.tw

Follow this and additional works at: https://jmstt.ntou.edu.tw/journal

Part of the Aquaculture and Fisheries Commons

\section{Recommended Citation}

Wu, Shao-Chi; Wang, Fu-Jin; and Pan, Chorng-Liang (2010) "THE COMPARISON OF ANTIOXIDATIVE PROPERTIES OF SEAWEED OLIGOSACCHARIDES FERMENTED BY TWO LACTIC ACID BACTERIA," Journal of Marine Science and Technology. Vol. 18: Iss. 4, Article 8.

DOI: $10.51400 / 2709-6998.1908$

Available at: https://jmstt.ntou.edu.tw/journal/vol18/iss4/8

This Research Article is brought to you for free and open access by Journal of Marine Science and Technology. It has been accepted for inclusion in Journal of Marine Science and Technology by an authorized editor of Journal of Marine Science and Technology. 
THE COMPARISON OF ANTIOXIDATIVE PROPERTIES OF SEAWEED OLIGOSACCHARIDES FERMENTED BY TWO LACTIC ACID BACTERIA

Acknowledgements

The authors are grateful to the National Science Council, Taiwan, R.O.C. for the financial support received for this work (Grant No. NSC 92-2313-B-019-021). 


\title{
THE COMPARISON OF ANTIOXIDATIVE PROPERTIES OF SEAWEED OLIGOSACCHARIDES FERMENTED BY TWO LACTIC ACID BACTERIA
}

\author{
Shao-Chi Wu*, Fu-Jin Wang**, and Chorng-Liang Pan***
}

Key words: agarases, seaweed oligosaccharides, lactic acid bacteria, antioxidative properties.

\begin{abstract}
The aim of this study was to investigate if the antioxidant properties of lactic acid bacteria (LAB) fermentation products have the potential to be used in future food materials. Twenty four LAB fermentation products, derived from two LAB strains, Enterococcus (Ent.; formerly Streptococcus) faecalis BCRC13076 and/or Lactobacillus (Lb.) rhamnosus BCRC14068 fermented through four seaweed polysaccharide extracts (SwPSExts) from Gelidium sp., Gracilaria sp., Monostroma (Mon.) nitidum, and Porphyra (Por.) dentate or their seaweed-oligosaccharide-lysates (SwOSLys) source digested by agarases, had their antioxidative properties evaluated by six in vitro methods. Seaweed oligosaccharide LAB fermentation product (SwOS-LAFP) showed a significantly greater reducing power, an increased chelating effect upon ferrous ions, an increased inhibition effect upon the hemoglobin-catalyzed peroxidation of linoleic acid, and an increased scavenging capacity upon hydrogen peroxide. However, it showed a reduced activity upon DPPH radicals compared to the seaweed polysaccharide LAB fermentation product (SwPS-LAFP). In 24 LAB fermentation products only two exhibited a scavenging effect upon hydroxyl radicals. These findings demonstrate that SwPS-LAFP and SwOS-LAFP possess significant antioxidant activity and suggest that AgPS-LAFPs and AgOS-LAFSs may be considered among the more promising food components for preventing oxidative damage.
\end{abstract}

Paper submitted 10/03/08; revised 07/28/09; accepted 08/10/09. Author for correspondence: Chorng-Liang Pan (e-mail: b0037@mail.ntou.edu.tw). *Department of Food Science and Technology, Tung-Fang Institute of Technology, Kaohsiung, Taiwan, R.O.C.

**Department of Tourism, Aletheia University, Taipei, Taiwan, R.O.C.

***Department of Food Science, National Taiwan Ocean University, Keelung, Taiwan, R.O.C.

\section{INTRODUCTION}

Oxidative stress has been reported to be the result of an imbalance that occurs when survival mechanisms are unable to deal adequately with reactive oxygen species (ROS) in the cells $[10,14,48]$. The interest in ROS in biology and medicine is obvious because of their strong relationship with phenomena such as Alzheimer's disease [16, 52], arthritis [30], cancer [35, 54], cardiovascular diseases [6, 31], diabetes [2, 8], tissue damage caused by ischemia-reperfusion [47], and Parkinson's disease [11, 61].

It has been observed that the production of reactive oxygen species (ROS) in algae is stimulated by various environmental stresses, such as high light levels, heavy metals, high salt concentrations, UV irradiation etc. Algae generally have higher antioxidative activity due to a higher content of various nonenzymatic antioxidant components, such as reduced glutathione (GSH), ascorbic acid, $\alpha$-tocopherol, $\beta$-carotenoids, flavonoids, hydroquinones, phycocyanin, proline, mannitol, myoinositol, phenolics, and/or polyamines $[15,41,51]$. As a result, according to many studies in the past few years, algae have become good candidates as a source of natural antioxidants [17, 19, 23, $40,63]$.

The ability of lactic acid bacteria to create the low oxidation-reduction potential needed for their optimum growth is probably related to some of these systems [25, 34]. Starter cultures with free radical scavenger properties would be useful in the food manufacturing industry. They could benefit the consumer by providing another dietary source of antioxidants, or by providing probiotic bacteria with the potential of producing antioxidants during growth in the intestinal tract [38, 44]. Some species of Lactobacillus (Lb.) and Streptococcus (Strep.) have been reported to produce antioxidative activity $[12,37]$. The intensity of antioxidative activity varied among the different cultures in each study. Most of these studies based the results on their evaluation of cell-free extracts of the lactic acid bacteria.

Our previous studies tested various seaweed oligosaccharides that were produced by agarases digested seaweed polysaccharide extract which were then fermented by two LAB 
strains, Ent. (formerly Strep.) faecalis BCRC13076 and Lb. rhamnosus BCRC14068 [56, 57]. Based on the fact that both algae and lactic acid bacteria have antioxidative capacities, the purpose of this study was to examine the effects of the antioxidative properties of the LAB fermentation product from seaweed oligosaccharides or polysaccharides by various antioxidative assays.

\section{MATERIALS AND METHODS}

\section{Crude Enzyme Preparation}

The preparation of two crude enzyme solutions of agarases from the strains Aeromonas salmonicida MAEF108 and Pseudomonas vesicularis MA103 were obtained according to the method used by Wu and Pan [55], and the assay of agarase activity was carried out according to the same reference.

\section{Lactic Acid Bacteria (LAB) Starter}

Two LAB strains, Ent. faecalis BCRC13076 and Lb. rhamnosus BCRC14068 were used as fermentation starter. They were obtained from the Bioresources Collection and Research Center (BCRC), Hsinchu, Taiwan. In the article of Wu et al. $[56,57]$, three LAB groups were carried out. These three LAB groups are: (1) Ent. faecalis BCRC13076, (2) Lb. rhamnosus BCRC14068, and (3) Ent. faecalis BCRC13076 and Lb. rhamnosus BCRC14068. Their abbreviations are: (1) LAB-BCRC13076, (2) LAB-BCRC14068, and (3) LAB-Comb, respectively.

\section{Types of Seaweed Polysaccharide Extract (SwPSExt)}

The seaweed polysaccharide extract (SwPSExt) of four seaweeds, Gelidium sp., Gracilaria sp., Monostroma (Mon.) nitidum, and Porphyra (Por.) dentate were prepared according to the protocol described in $\mathrm{Wu}$ and Pan [55]. The four SwPSExts from Gelidium sp., Gracilaria sp., Mon. nitidum, and Por. dentate are abbreviated as Gel, Gra, Mon, and Por, respectively. The seaweed extracts were composed of ash $(4.4 \%-11.33 \%)$, protein $(0.31 \%-4.13 \%)$, and the rest was carbohydrate $(28.72 \%-49.25 \%)$ in the form of polysaccharide (data not shown).

\section{Preparation of Seaweed Polysaccharide LAB Fermentation Solution (SwPS-LAFS)}

According to the method used by Wu et al. [56, 57], $100 \mathrm{~mL}$ of $0.5 \%$ four SwPSExt (Gel, Gra, Mon, and Por) were placed in a $125 \mathrm{~mL}$ glass bottle with a screw cap, and $5 \mathrm{~mL}$ of a nitrogen source solution was added which contained $1.0 \mathrm{~g}$ of beef extract (Sigma, Chemical Co., St. Louis, MO, U.S.A.) and $0.5 \mathrm{~g}$ of yeast extract (Sigma). Then, LAB starter of three LAB groups as mentioned above were used for the seaweed polysaccharide fermentation by lactic acid bacteria until the $\mathrm{pH}$ value reached 4.4 to 4.6 , which was taken as the terminal point of the fermentation. The seaweed polysaccharide solutions which were obtained from the $12 \mathrm{LAB}$ fermentation samples are referred to as seaweed polysaccharide LAB fermentation solution (SwPS-LAFS). The fermentation solutions derived from Gel fermented with LAB-BCRC13076 is referred to as 13076-Gel-SwPS-LAFS in this article; all other 11 SwPS-LAFS are named by the same rule.

\section{Preparation of Seaweed Oligosaccharides LAB Fermentation Solution (SwOS-LAFS)}

According to the method used by Wu et al. [58], $105 \mathrm{~mL}$ of seaweed oligosaccharides solution (SwOSS) was obtained from four different seaweed types (Gel, Gra, Mon, and Por, respectively), and contained $5 \mathrm{~mL}$ nitrogen source solution composed of $1.0 \mathrm{~g}$ of beef extract and $0.5 \mathrm{~g}$ of yeast extract. This was placed in a $125 \mathrm{~mL}$ glass bottle with a screw cap. Then, LAB starter of three LAB groups as mentioned above were used for the fermentation of the SwOSS by lactic acid bacteria until the $\mathrm{pH}$ value reached 4.4 to 4.6 , which was taken as the terminal point of the fermentation. The 12 LAB fermentation samples obtained from the LAB fermented SwOSS are referred to as the seaweed oligosaccharide LAB fermentation solution (SwOS-LAFS). The fermentation solution derived from Gel that fermented with LAB-BCRC13076 is called 13076-Gel-SwOS-LAFS in this article; all other 11 SwOS-LAFS are named using the same method.

\section{Preparation of LAB Fermentation Product for Testing}

First, the LAB fermentation solution of (A) SwPS-LAFS or (B) SwOS-LAFS were centrifuged at $10,000 \times \mathrm{g}$ at $4^{\circ} \mathrm{C}$ for 30 min using a high-speed refrigerated centrifuge (Himac CR 21, Hitachi, Tokyo, Japan). Then, the upper layer was placed into $50 \mathrm{~mL}$ centrifuge tubes (Hitachi, Tokyo, Japan) using $0.2 \mu \mathrm{m}$ filter membrane (47 mm; Millex-GS, Millipore Corp., U.S.A.) to filter the LAB fermentation solution and obtain the sterile samples. Finally, the sterile LAB fermentation samples were named (a) seaweed polysaccharide LAB fermentation product (SwPS-LAFP) or (b) seaweed oligosaccharide LAB fermentation product (SwOS-LAFP). Due to the fact that the reducing sugar concentrations of the LAB fermentation product ranged from 5.2-19.2 mg/mL D-galactose (data not shown), the reducing sugar concentration of the LAB fermentation products were adjusted to $5 \mathrm{mg} / \mathrm{mL}$. Finally, the sterilized $\mathrm{LAB}$ fermentation products were stored in a refrigerator (GR-B500A, LG, Seoul, Korea) at $4{ }^{\circ} \mathrm{C}$ for determining their antioxidative effects.

\section{Methods to Determine Anti-oxidative Effects}

\section{1) Reducing Power}

The reducing power of the LAB fermentation products were measured by a method derived from a previous method $[55,58]$. Each LAB fermentation product was mixed with 200 $\mathrm{mM}$ sodium phosphate buffer $(\mathrm{pH}$ 6.6) and $1 \%$ potassium ferricyanide (Sigma). This mixture was then incubated at $50^{\circ} \mathrm{C}$ for $20 \mathrm{~min}$. Then, $10 \%$ trichloroacetic acid (w/v) (Panreac, Spain) was added, and the mixture was centrifuged. The 
upper layer was mixed with de-ionized water and $0.1 \%$ ferric chloride (Merck, Germany), and the absorbance was determined at $700 \mathrm{~nm}$. The higher the absorbance, the higher the reducing power; reducing power is expressed as: $\mathrm{x} \mu \mathrm{g} / \mathrm{mL}$ of ascorbic acid (AA).

\section{2) $\alpha$-Diphenyl- $\alpha$-Picrylhydrazyl (DPPH) Assay}

The DPPH free radical scavenging capacities of the LAB fermentation products were measured using the method reported previously $[55,58]$. LAB fermentation products were mixed with $0.1 \mathrm{mM}$ DPPH (Sigma) ethanol solution and 50 $\mathrm{mM}$ Tris-HCl buffer ( $\mathrm{pH}$ 7.4) solution. Methanol (Panreac) was used as a control. After $30 \mathrm{~min}$, the reduction of the DPPH free radicals was measured at $517 \mathrm{~nm}$ absorbance. As reported in Ahn et al. [1], the concentration of L-ascorbic acid (Sigma) at $1 \mathrm{mg} / \mathrm{mL}$ was used as a positive control. The inhibition ratio was calculated from Equation (1) as follows.

$\%$ inhibition $=[($ absorbance of control - absorbance of test sample)/absorbance of control] $\times 100$.

\section{3) Inhibition of the Hemoglobin-Catalyzed Peroxidation of Linoleic Acid}

Inhibition of the hemoglobin-catalyzed peroxidation of linoleic acid was determined after the method of Kuo et al. [26]. The LAB fermentation products $(20 \mu \mathrm{L})$ were mixed with 0.3 $\mathrm{mL}$ of $0.05 \mathrm{M}$ phosphate buffer $(\mathrm{pH} 7.0)$ containing $0.04 \%$ Tween 20 (Sigma) and $20 \mu \mathrm{L}$ of $100 \mathrm{mM}$ linoleic acid (Sigma). They were then equilibrated at $37^{\circ} \mathrm{C}$ for $3 \mathrm{~min}$. The peroxidation of linoleic acid in the above reaction mixture was initiated by adding $50 \mu \mathrm{L}$ of $0.003 \%$ hemoglobin (Sigma) in water, followed by incubation at $37^{\circ} \mathrm{C}$ for $10 \mathrm{~min}$, and then stopped by adding $5 \mathrm{~mL}$ of $0.6 \% \mathrm{HCl}$ (in ethanol). The thiocyanate (FTC) method was then used to quantify the peroxidation of linoleic acid, in the order of $0.1 \mathrm{~mL}$ of $\mathrm{FeCl}_{2}$ solution $(0.02 \mathrm{M})$ and $0.1 \mathrm{~mL}$ of ammonium thiocyanate (Panreac) solution $(30 \%)$ were added to $1.6 \mathrm{~mL}$ of the sample solution at $37^{\circ} \mathrm{C}$ for $5 \mathrm{~min}$. The absorbance of the mixture was determined at $480 \mathrm{~nm}$. As reported in Rupérez et al. [43] the concentration at $1 \mathrm{mg} / \mathrm{mL}$ of Trolox (Acros Organics N. V., Geel, Belgium) was used as a positive control. The inhibition effect (percent) was calculated according to Equation (1).

\section{4) Chelating Effect on Ferrous Ions}

The chelating effect on ferrous ions was determined according to a previous method $[55,58]$. The LAB fermentation products were mixed with methanol and $400 \mu \mathrm{M} \mathrm{FeCl}_{2}$ (Merck), followed by the addition of $2 \mathrm{mM}$ ferrozine (Sigma). After $10 \mathrm{~min}$ the absorbance of the mixture was determined at $562 \mathrm{~nm}$. Trolox was used as a positive control [43]. The chelating effect (\%) was calculated by Equation (1).

\section{5) Scavenging Capacity of Hydrogen Peroxide $\left(\mathrm{H}_{2} \mathrm{O}_{2}\right)$}

The scavenging capacity of $\mathrm{H}_{2} \mathrm{O}_{2}$ was measured using a previous method $[55,58]$. The LAB fermentation products were added to $5 \mathrm{mM} \mathrm{H}_{2} \mathrm{O}_{2}$ (Showa, Tokyo, Japan). After preincubation for $20 \mathrm{~min}$, HRPase-phenol red in a $0.1 \mathrm{M}$ phosphate buffer was added. After $10 \mathrm{~min}$ the absorbance at 610 $\mathrm{nm}$ was measured. The method reported by Yen et al. [60] was followed, using $1 \mathrm{mg} / \mathrm{mL} \mathrm{L-ascorbic} \mathrm{acid} \mathrm{(Sigma)} \mathrm{as} \mathrm{the} \mathrm{posi-}$ tive control. The scavenging capacity $(\%)$ was calculated in a manner similar to Equation (1).

\section{6) Hydroxyl Radicals Scavenging Effect}

The scavenging effect of hydroxyl radicals was measured using the method of Halliwell et al. [21], and the results depended on the effect of deoxyribose degradation catalyzed by $\mathrm{Fe}(\mathrm{III})-\mathrm{EDTA}$. Then $0.1 \mathrm{~mL}$ of $28 \mathrm{mM}$ deoxyribose (Sigma), $0.4 \mathrm{~mL}$ of $40 \mathrm{mM}$ phosphate buffer (pH 7.4), $0.1 \mathrm{~mL}$ of $1 \mathrm{mM}$ $\mathrm{FeCl}_{3} \cdot 6 \mathrm{H}_{2} \mathrm{O}$ (Merck), $0.1 \mathrm{~mL}$ of $1.04 \mathrm{mM}$ EDTA (Panreac), $0.1 \mathrm{~mL}$ of $10 \mathrm{mM} \mathrm{H}_{2} \mathrm{O}_{2}$ (Showa), $0.1 \mathrm{~mL}$ of $1 \mathrm{mM} \mathrm{L}$-ascorbic acid (Sigma), and $0.1 \mathrm{~mL}$ of the LAB fermentation products were added together in test tubes, and mixed well. The reaction was carried out at $37^{\circ} \mathrm{C}$ in a water bath for $1 \mathrm{~h}$. Next, 0.5 $\mathrm{mL}$ of $1 \%$ 2-Thiobarbituric acid (Sigma) and $0.5 \mathrm{~mL}$ of $2.8 \%$ Trichloroacetic acid (Panreac) were added to each of these test tubes. The mixture was placed at $100^{\circ} \mathrm{C}$ in a hot water bath for $10 \mathrm{~min}$, and then cooled to room temperature. The mixture was centrifuged at $1,630 \times \mathrm{g}$ for $10 \mathrm{~min}$, using a low-speed refrigerated centrifuge (CF 7D2, Hitachi). The upper layer was taken to measure the absorbance at $532 \mathrm{~nm}$. D-mannitol (Sigma) was used as a positive control [43]. The scavenging effect (\%) was calculated by Equation (1).

\section{Statistical Analysis}

All antioxidative results from the LAB fermentation products are expressed as mean $\pm \mathrm{SD}(n=3)$. Data were analyzed by one-way analysis of variance (ANOVA). When the ANOVA identified differences among groups, multiple comparisons among means were made using Duncan's new multiple range test. Statistical significance was determined by setting the aggregate type I error at $5 \%(p<0.05)$ for each set of comparisons, using the Statistical Analysis System software package [46].

\section{RESULTS AND DISCUSSION}

\section{Reducing Power}

Some studies reported that the reducing capacity of a compound may serve as a significant indicator of its potential antioxidant activity [9, 22, 29]. The results of the reducing power of (A) 12 SwPS-LAFP which is derived from SwPSLAFS or (B) 12 SwOS-LAFP which is derived from SwOSLAFS fermented by LAB BCRC13076 and/or BCRC14068 are shown in Table 1. The reducing power of the $24 \mathrm{LAB}$ fermentation products was in the range of $10.1 \pm 0.4$ (14068Por-SwPS-LAFP) to $27.0 \pm 1.3$ (13076-Gel-SwOS-LAFP) $\mu \mathrm{g} / \mathrm{mL}$ of ascorbic acid (AA), and SwOS-LAFPs were better than SwPS-LAFPs for the same seaweed type. In addition, the 
Table 1. Reducing power of (A) 12 SwPS-LAFP which is derived from SwPS-LAFS or (B) 12 SwOS-LAFP derived from SwOS-LAFS fermented with LAB BCRC13076 and/or BCRC14068.

\begin{tabular}{c|c|cccc}
\hline \multirow{2}{*}{ Strain } & Fermentation product & \multicolumn{4}{|c}{ Equal to x $\mu \mathrm{g} / \mathrm{mL}$ ascorbic acid } \\
\cline { 3 - 5 } & & Gel $^{* * *}$ & Gra & Mon & Por \\
\hline \multirow{2}{*}{13076} & SwPS-LAFP** & $16.1 \pm 0.4^{\mathrm{c}[\mathrm{B}]}$ & $15.1 \pm 0.7^{\mathrm{c}[\mathrm{C}]}$ & $17.4 \pm 0.4^{\mathrm{c}[\mathrm{A}]}$ & $14.6 \pm 0.4^{\mathrm{c}[\mathrm{C}]}$ \\
& SwOS-LAFP & $27.0 \pm 1.3^{\mathrm{a}[\mathrm{A}]}$ & $18.2 \pm 0.7^{\mathrm{b}[\mathrm{C}]}$ & $24.4 \pm 0.5^{\mathrm{a}[\mathrm{B}]}$ & $26.9 \pm 0.5^{\mathrm{a}[\mathrm{A}]}$ \\
& SwPS-LAFP & $14.3 \pm 0.9^{\mathrm{d}[\mathrm{A}]}$ & $14.3 \pm 0.9^{\mathrm{c}[\mathrm{A}]}$ & $14.7 \pm 0.6^{\mathrm{d}[\mathrm{A}]}$ & $10.1 \pm 0.4^{\mathrm{e}[\mathrm{B}]}$ \\
\multirow{2}{*}{14068} & SwOS-LAFP & $25.9 \pm 0.4^{\mathrm{ab}[\mathrm{A}]}$ & $25.4 \pm 2.1^{\mathrm{a}[\mathrm{A}]}$ & $21.1 \pm 0.5^{\mathrm{b}[\mathrm{B}]}$ & $25.2 \pm 0.5^{\mathrm{b}[\mathrm{A}]}$ \\
& SwPS-LAFP & $16.6 \pm 0.3^{\mathrm{c}[\mathrm{A}]}$ & $14.8 \pm 0.1^{\mathrm{c}[\mathrm{B}]}$ & $17.1 \pm 0.4^{\mathrm{c}[\mathrm{A}]}$ & $12.6 \pm 0.2^{\mathrm{d}[\mathrm{C}]}$ \\
& SwOS-LAFP & $25.0 \pm 0.6^{\mathrm{b}[\mathrm{B}]}$ & $24.5 \pm 0.7^{\mathrm{a}[\mathrm{B}]}$ & $24.1 \pm 0.4^{\mathrm{a}[\mathrm{B}]}$ & $26.4 \pm 0.5^{\mathrm{a}[\mathrm{A}]}$ \\
\hline
\end{tabular}

* Data are mean values of triplicate determinations \pm standard deviation. Different superscript small letters in the same column (vertical comparison) or capital letters in the same row (horizontal comparison) of brackets indicate significantly different values $(p<0.05)$.

** SwPS-LAFP, seaweed polysaccharide LAB fermentation product; SwOS-LAFP, seaweed oligosaccharide LAB fermentation product.

*** Gel, Gra, Mon, and Por represent SwPSExt are derived from Gelidium sp., Gracilaria sp., Mon. nitidum, and Por. dentate, respectively.

Table 2. DPPH radical scavenging effect (\%) of (A) 12 SwPS-LAFP which is derived from SwPS-LAFS or (B) 12 SwOSLAFP derived from SwOS-LAFS fermented with LAB BCRC13076 and/or BCRC14068.

\begin{tabular}{|c|c|c|c|c|c|}
\hline \multirow{2}{*}{ Strain } & \multirow{2}{*}{ Fermentation product } & \multicolumn{4}{|c|}{ Scavenging effect $(\%)$} \\
\hline & & $\mathrm{Gel}^{* * *}$ & Gra & Mon & Por \\
\hline \multirow{2}{*}{13076} & SwPS-LAFP** & $57.1 \pm 1.2^{\mathrm{d}[\mathrm{B}]}$ & $61.5 \pm 1.8^{\mathrm{c}[\mathrm{A}]}$ & $57.0 \pm 2.0^{\mathrm{c}[\mathrm{B}]}$ & $63.6 \pm 0.2^{\mathrm{d}[\mathrm{A}]}$ \\
\hline & SwOS-LAFP & $36.2 \pm 2.2^{\mathrm{e}[\mathrm{C}]}$ & $42.9 \pm 0.5^{\mathrm{e}[\mathrm{B}]}$ & $44.2 \pm 1.9^{\mathrm{d}[\mathrm{B}]}$ & $55.3 \pm 1.9^{\mathrm{e}[\mathrm{A}]}$ \\
\hline \multirow{2}{*}{14068} & SwPS-LAFP & $65.9 \pm 0.7^{\mathrm{b}[\mathrm{D}]}$ & $71.5 \pm 1.2^{\mathrm{a}[\mathrm{C}]}$ & $73.8 \pm 0.3^{\mathrm{a}[\mathrm{B}]}$ & $79.6 \pm 1.0^{\mathrm{a}[\mathrm{A}]}$ \\
\hline & SwOS-LAFP & $63.7 \pm 0.6^{\mathrm{bc}[\mathrm{B}]}$ & $55.9 \pm 1.6^{\mathrm{d}[\mathrm{C}]}$ & $72.5 \pm 1.5^{\mathrm{a}[\mathrm{A}]}$ & $75.0 \pm 1.8^{\mathrm{b}[\mathrm{A}]}$ \\
\hline \multirow{2}{*}{ Comb } & SwPS-LAFP & $69.6 \pm 1.4^{\mathrm{a}[\mathrm{B}]}$ & $68.7 \pm 0.5^{\mathrm{b}[\mathrm{B}]}$ & $64.5 \pm 0.9^{\mathrm{b}[\mathrm{C}]}$ & $72.5 \pm 2.1^{\mathrm{bc}[\mathrm{A}]}$ \\
\hline & SwOS-LAFP & $62.2 \pm 1.0^{\mathrm{c}[\mathrm{B}]}$ & $54.7 \pm 0.7^{\mathrm{d}[\mathrm{C}]}$ & $55.9 \pm 0.7^{\mathrm{c}[\mathrm{C}]}$ & $70.6 \pm 1.8^{\mathrm{c}[\mathrm{A}]}$ \\
\hline
\end{tabular}

* Data are mean values of triplicate determinations \pm standard deviation. Different superscript small letters in the same column (vertical comparison) or capital letters in the same row (horizontal comparison) of brackets indicate significantly different values $(p<0.05)$.

** SwPS-LAFP, seaweed polysaccharide LAB fermentation product; SwOS-LAFP, seaweed oligosaccharide LAB fermentation product.

*** Gel, Gra, Mon, and Por represent SwPSExt are derived from Gelidium sp., Gracilaria sp., Mon. nitidum, and Por. dentate, respectively.

reducing power of SwPS-LAFP and SwOS-LAFP which were fermented by LAB-BCRC13076, LAB-BCRC14068, or LAB-Comb, were as follows: (i) 13076-Por-SwOS-LAFP was 1.8-fold higher than 13076-Por-SwPS-LAFP; (ii) 14068Por-SwOS-LAFP was 2.5-fold higher than 14068-Por-SwPSLAFP; and (iii) com-Por-SwOS-LAFP was 2.1-fold higher than Com-Por-SwPS-LAFP, respectively.

Thus, it appears necessary to determine the reducing power of SwPS-LAFP or SwOS-LAFP to elucidate the relationship between their antioxidant effect and their reducing power. In our previous study, the SwPSExts or SwOSLys which was the raw material for SwPS-LAFP or SwOS-LAFP also showed antioxidative properties and reducing power. The reducing power of SwPS-LAFPs was greater than that of SwPSExts, except for SwPSExt from Por. dentate. However, it appears that an increase of either SwOS-LAFP or SwOSLys had no relationship with the reducing power. Several workers have found that the reducing power of fermented milk was significantly greater than milk and suggested that certain metabolites, such as glutathione, that demonstrate superior re- ducing power might be produced during kefir fermentation and that they could possibly react with free radicals to stabilize and terminate radical chain reactions [20, 28, 39].

\section{2. $\alpha$-Diphenyl-a-Picrylhydrazyl (DPPH) Assay}

Proton radical-scavenging has been reported to be an important mechanism for antioxidation. The decrease in absorbance of DPPH radicals is caused by antioxidants through the reaction between antioxidant molecules and radicals, resulting in the scavenging of the radicals by hydrogen donation. This is visually noticeable as a discoloration from purple to yellow. Hence, DPPH is usually used as a substrate to evaluate the activity of antioxidants [4]. The reduction in the concentration of the DPPH allows monitoring the decrease in absorbance at a characteristic wavelength when proton-radical scavengers are encountered [59]. The scavenging effects (\%) on DPPH radicals of (A) 12 SwPS-LAFP which are derived from SwPS-LAFS or (B) 12 SwOS-LAFP which are derived from SwOS-LAFS fermented by LAB BCRC13076 and/or BCRC14068 are shown in Table 2. The scavenging effects 
Table 3. Ferrous ion chelating effect (\%) of (A) 12 SwPS-LAFP which is derived from SwPS-LAFS or (B) 12 SwOSLAFP derived from SwOS-LAFS fermented with LAB BCRC13076 and/or BCRC14068.

\begin{tabular}{c|c|cccc}
\hline \multirow{2}{*}{ Strain } & \multirow{2}{*}{ Fermentation product } & \multicolumn{4}{|c}{ Chelating effect (\%) } \\
\cline { 3 - 5 } & & Gel $^{* * *}$ & Gra & Mon & Por \\
\hline \multirow{2}{*}{13076} & SwPS-LAFP** & $40.4 \pm 2.9^{\mathrm{d}[\mathrm{B}]}$ & $41.0 \pm 2.0^{\mathrm{d}[\mathrm{B}]}$ & $75.2 \pm 2.2^{\mathrm{b}[\mathrm{A}]}$ & $36.1 \pm 1.4^{\mathrm{d}[\mathrm{C}]}$ \\
& SwOS-LAFP & $74.9 \pm 1.9^{\mathrm{b}[\mathrm{B}]}$ & $73.2 \pm 1.5^{\mathrm{b}[\mathrm{B}]}$ & $82.1 \pm 1.2^{\mathrm{a}[\mathrm{A}]}$ & $66.4 \pm 0.8^{\mathrm{c}[\mathrm{C}]}$ \\
& SwPS-LAFP & $20.6 \pm 1.4^{\mathrm{e}[\mathrm{D}]}$ & $40.0 \pm 0.5^{\mathrm{d}[\mathrm{A}]}$ & $30.6 \pm 1.9^{\mathrm{d}[\mathrm{C}]}$ & $36.8 \pm 1.1^{\mathrm{d}^{[\mathrm{B}]}}$ \\
\multirow{2}{*}{14068} & SwOS-LAFP & $56.2 \pm 1.1^{\mathrm{c}[\mathrm{C}]}$ & $56.1 \pm 0.9^{\mathrm{c}[\mathrm{C}]}$ & $82.1 \pm 0.2^{\mathrm{a}[\mathrm{A}]}$ & $78.3 \pm 0.7^{\mathrm{b}[\mathrm{B}]}$ \\
& SwPS-LAFP & $41.2 \pm 1.3^{\mathrm{d}[\mathrm{AB}]}$ & $24.0 \pm 1.9^{\mathrm{e}[\mathrm{C}]}$ & $43.1 \pm 2.9^{\mathrm{c}[\mathrm{A}]}$ & $37.7 \pm 0.4^{\mathrm{d}[\mathrm{B}]}$ \\
& SwOS-LAFP & $78.5 \pm 0.2^{\mathrm{a}[\mathrm{C}]}$ & $78.3 \pm 0.3^{\mathrm{a}[\mathrm{C}]}$ & $84.4 \pm 0.3^{\mathrm{a}[\mathrm{A}]}$ & $83.0 \pm 0.6^{\mathrm{a}[\mathrm{B}]}$ \\
\hline
\end{tabular}

* Data are mean values of triplicate determinations \pm standard deviation. Different superscript small letters in the same column (vertical comparison) or capital letters in the same row (horizontal comparison) of brackets indicate significantly different values $(p<0.05)$.

** SwPS-LAFP, seaweed polysaccharide LAB fermentation product; SwOS-LAFP, seaweed oligosaccharide LAB fermentation product.

*** Gel, Gra, Mon, and Por represent SwPSExt are derived from Gelidium sp., Gracilaria sp., Mon. nitidum, and Por. dentate, respectively.

(\%) on DPPH radicals of the $24 \mathrm{LAB}$ fermentation products were in the range of $36.2 \pm 2.2(13076-G e l-S w O S-L A F P)$ to $79.6 \pm 1.0$ (14068-Por-SwPS-LAFP), and their scavenging effects (\%) on DPPH radicals of SwOS-LAFPs were smaller than SwPS-LAFPs for the same seaweed type. In addition, when comparing SwPS-LAFP and SwOS-LAFP, which were fermented by LAB-BCRC13076, LAB-BCRC14068, or LABComb, the results were as follows (i) 13076-Gra-SwOS-LAFP or 13076-Por-SwOS-LAFP were 0.6-fold lower than 13076Gra-SwPS-LAFP or 13076-Por-SwPS-LAFP; (ii) 14068-GelSwOS-LAFP or 14068-Mon-SwOS-LAFP were 1.0-fold lower than 14068-Gel-SwPS-LAFP or 14068-Mon-SwPS-LAFP; and (iii) com-Por-SwOS-LAFP was 1.0-fold lower than Com-PorSwPS-LAFP, respectively.

In the present study, the antioxidative capability of 12 SwOS-LAFP on DPPH radical-scavenging activity was smaller than that of SwPS-LAFP. Many investigators explain decreasing of DPPH radical-scavenging activity, such as McCuea and Shetty $[32,33]$ believed that the degradation of polymeric phenolic structures after being fermented by microorganisms may explain the increase in soluble phenolic content thereby decreasing antioxidant activity. Rohn et al. [42] prove the covalent attachment of quercetin to bovine serum albumin decreases the total antioxidant activity in comparison to an equivalent amount of free quercetin depending on the degree of derivatization. Kevers et al. [24] explain antioxidant capacity (DPPH) decrease drastically during storage that reserve at low temperature, cause by phenol content reduce.

\section{Chelating Effect on Ferrous Ions}

Iron, the most abundant transition-metal ion in the human body, may work as a catalyst for the generation of reactive oxygen species under pathological conditions [50]. In the presence of low concentrations of transition-metal ions, hydroxyl radicals are formed from hydrogen peroxide via the Fenton reaction [3]. Table 3 shows the test results of (A) 12 SwPS-LAFP which are derived from SwPS-LAFS or (B) 12 SwOS-LAFP which are derived from SwOS-LAFS fermented by LAB BCRC13076 and/or BCRC14068, on the chelating effect on ferrous ions $(\%)$. The results of the chelating capacity on ferrous ions on the $24 \mathrm{LAB}$ fermentation products was in the range of $24.0 \pm 1.9$ (Comb-Gra-SwPS-LAFP) to $84.4 \pm 0.3$ (Comb-Mon-SwOS-LAFP), and their chelating capacity on ferrous ions of SwOS-LAFPs were better than SwPS-LAFPs for the same seaweed type. In addition, when comparing SwPS-LAFP and SwOS-LAFP, which were fermented by LABBCRC13076, LAB-BCRC14068, or LAB-Comb, the results of (i) 13076-Gel-SwOS-LAFP was 1.9-fold higher than 13076Gel-SwPS-LAFP; (ii) 14068-Gel-SwOS-LAFP or 14068-MonSwOS-LAFP were 2.7-fold higher than 14068-Gel-SwPS-LAFP or 14068-Mon-SwPS-LAFP; and (iii) Comb-Gra-SwOS-LAFP was 3.6 fold higher than Comb-Gra-SwPS-LAFP.

Because SwPS-LAFPs or SwOS-LAFPs that used beef extract and yeast extract as a nitrogen source were fermented by $\mathrm{LAB}$, the protein contents in the beef extract and yeast extract could bind ferric or ferrous ions. Liu et al. [28] also pointed out the ability of milk proteins to bind ferric or ferrous ions, e.g., lactoferrin, serum albumin, casein, and a high molecular-weight fraction of whey, all of which have been reported to demonstrate some iron-chelating activity.

\section{Inhibition of the Hemoglobin-Catalyzed Peroxidation of Linoleic Acid}

Lipid peroxidation is a process by which polyunsaturated fatty acids present in cell membranes are broken down into various products such as hydrocarbon gases, cytotoxic aldehydes and free oxygen radicals [18]. Therefore, the inhibition of lipid peroxidation is of great importance to the prevention of certain human disease processes involving free radicals. Table 4 shows the inhibition effects (\%) on the hemoglobincatalyzed peroxidation of linoleic acid of (A) 12 SwPS-LAFP which is derived from SwPS-LAFS or (B) 12 SwOS-LAFP derived from SwOS-LAFS fermented by LAB BCRC13076 and/or BCRC14068. The hemoglobin catalyzed peroxidation of linoleic acid inhibition of the 24 LAB fermentation products was in the range of $7.9 \pm 5.5$ (14068-Gra-SwPS-LAFP) 
Table 4. Inhibition (\%) of the hemoglobin-catalyzed peroxidation of linoleic acid of (A) 12 SwPS-LAFP which is derived from SwPS-LAFS or (B) 12 SwOS-LAFP derived from SwOS-LAFS fermented with LAB BCRC13076 and/or BCRC14068.

\begin{tabular}{c|c|cccc}
\hline \multirow{2}{*}{ Strain } & Fermentation product & \multicolumn{4}{|c}{ Inhibition $(\%)$} \\
\cline { 3 - 5 } & & Gel $^{* * *}$ & Gra & Mon & Por \\
\hline \multirow{2}{*}{13076} & SwPS-LAFP** & $18.9 \pm 4.0^{\mathrm{c}[\mathrm{B}]}$ & $36.6 \pm 0.0^{\mathrm{c}[\mathrm{A}]}$ & $12.6^{*} \pm 4.5^{\mathrm{d}[\mathrm{C}]}$ & $18.9 \pm 1.0^{\mathrm{e}[\mathrm{B}]}$ \\
& SwOS-LAFP & $87.1 \pm 3.1^{\mathrm{a}[\mathrm{A}]}$ & $53.1 \pm 8.0^{\mathrm{b}[\mathrm{C}]}$ & $64.7 \pm 4.1^{\mathrm{a}[\mathrm{B}]}$ & $73.2 \pm 4.8^{\mathrm{b}[\mathrm{B}]}$ \\
& SwPS-LAFP & $19.0 \pm 4.8^{\mathrm{c}[\mathrm{A}]}$ & $7.9 \pm 5.5^{\mathrm{d}[\mathrm{B}]}$ & $17.5 \pm 2.7^{\mathrm{cd}[\mathrm{A}]}$ & $22.2 \pm 2.7^{\mathrm{e}[\mathrm{A}]}$ \\
\multirow{2}{*}{14068} & SwOS-LAFP & $24.2 \pm 6.9^{\mathrm{bc}[\mathrm{C}]}$ & $33.3 \pm 2.0^{\mathrm{c}[\mathrm{C}]}$ & $45.8 \pm 7.9^{\mathrm{b}[\mathrm{B}]}$ & $63.4 \pm 2.3^{\mathrm{c}[\mathrm{A}]}$ \\
& SwPS-LAFP & $32.9 \pm 9.7^{\mathrm{b}[\mathrm{AB}]}$ & $35.4 \pm 5.7^{\mathrm{c}[\mathrm{AB}]}$ & $24.8 \pm 2.8^{\mathrm{c}[\mathrm{B}]}$ & $40.4 \pm 4.9^{\mathrm{d}[\mathrm{A}]}$ \\
& SwOS-LAFP & $77.5 \pm 1.3^{\mathrm{a}[\mathrm{BC}]}$ & $84.8 \pm 3.8^{\mathrm{a}[\mathrm{B}]}$ & $73.2 \pm 7.6^{\mathrm{a}[\mathrm{C}]}$ & $93.5 \pm 2.2^{\mathrm{a}[\mathrm{A}]}$ \\
\hline
\end{tabular}

* Data are mean values of triplicate determinations \pm standard deviation. Different superscript small letters in the same column (vertical comparison) or capital letters in the same row (horizontal comparison) of brackets indicate significantly different values $(p<0.05)$.

** SwPS-LAFP, seaweed polysaccharide LAB fermentation product; SwOS-LAFP, seaweed oligosaccharide LAB fermentation product.

*** Gel, Gra, Mon, and Por represent SwPSExt are derived from Gelidium sp., Gracilaria sp., Mon. nitidum, and Por. dentate, respectively.

to $93.5 \pm 2.2$ (Comb-Por-SwOS-LAFP), and their inhibition effects on the hemoglobin-catalyzed peroxidation of linoleic acid of SwOS-LAFPs were better than SwPS-LAFPs for the same seaweed type. In addition, when comparing SwPS-LAFP and SwOS-LAFP which were fermented by LAB-BCRC13076, LAB-BCRC14068, or LAB-Comb, the results of (i) 13076-GelSwOS-LAFP was 4.6-fold higher than 13076-Gel-SwPS-LAFP; (ii) 14068-Gra-SwOS-LAFP was 4.2-fold higher than 14068Gra-SwPS-LAFP; and (iii) Comb-Mon-SwOS-LAFP was 2.9fold higher than Comb-Mon-SwPS-LAFP, respectively.

Terahara et al. [49] continued research also showed that ether extracts from two yogurt starters, Strep. thermophilus 1131 and Lb. delbrueckii subsp. bulgaricus 2308, could inhibit the oxidation of erythrocyte membranes in vitro and lowdensity lipoproteins in vivo. Zommara et al. [62] investigated the effect of whey from bovine skim milk fermented with bifidobacteria and found that lactic acid bacteria had a specific effect on oxidative stress. Liu et al. [28] found that the inhibitory effect upon linoleic acid peroxidation of milk-kefir and soymilk-kefir were significantly greater than those of milk and soymilk after being incubated for $32 \mathrm{~h}$. Pena-Ramos and Xiong [36], and Wong and Kitts [53] reported that proteins derived from dairy products, or peptides derived from milk protein hydrolysates inhibited lipid oxidation. This suggested that the specific amino acid residue side-chain groups or the specific peptide structure of the antioxidative peptides may be attributable to the chelation of prooxidative metal ions and the termination of the radical chain reactions. Sakanaka et al. [45] reported that peptides hydrolysates from casein calcium have a strong effect on the discoloration of $\beta$-carotene when analyzed for their antioxidant activity by the $\beta$-carotene bleaching assay. In our data (not shown) the soluble protein content of SwPSLAFPs or SwOS-LAFPs was greater than that of their SwPSExts or SwOSSs. Thus, we suggest that the peptides derived from beef extract and yeast extract proteins might contribute to the inhibitory effects of SwPS-LAFPs or SwOS-LAFPs upon lipid peroxidation.

\section{Hydrogen Peroxide $\left(\mathrm{H}_{2} \mathrm{O}_{2}\right)$ Scavenging Capacity and Hydroxyl Radicals Scavenging Effect}

It is well known that the $\mathrm{O}_{2}$ molecule has low reactivity and that its toxicity stems mainly from its excited state (singlet oxygen) or from its semi-reduced radical forms that can cause deleterious or lethal oxidative damage to the cells [13]. The four electron reduction of $\mathrm{O}_{2}$ to $\mathrm{H}_{2} \mathrm{O}$ gives rise successively to the formation of the reactive oxygen intermediates superoxide radical anion $\left(\mathrm{O}_{2}^{-}\right)$, hydrogen peroxide $\left(\mathrm{H}_{2} \mathrm{O}_{2}\right)$, and hydroxyl radical $\left(\mathrm{HO}^{\circ}\right)$. Several models have been proposed to explain the mechanism of $\mathrm{O}_{2}$ sensitivity in microorganisms. $\mathrm{O}_{2}{ }^{-}$and $\mathrm{H}_{2} \mathrm{O}_{2}$ are moderately reactive in aqueous solutions, but they both contribute to the formation of the highly reactive oxidant $\mathrm{HO}^{\bullet}$ via the Fenton and Haber-Weiss reactions. In bacteria, generation of the $\mathrm{HO}^{\bullet}$ radical is facilitated by the presence of $\mathrm{O}_{2}{ }^{-}, \mathrm{H}_{2} \mathrm{O}_{2}$ and free iron. Cellular components such as hemoproteins, lipids and DNA are targets for $\mathrm{HO}^{\bullet}$ forming a sitespecific Fenton-driven mechanism. Therefore, its removal is required to ensure cellular homeostasis [5].

The $\mathrm{H}_{2} \mathrm{O}_{2}$ scavenging capacity (\%) of (A) 12 SwPS-LAFP which is derived from SwPS-LAFS or (B) 12 SwOS-LAFP which is derived from SwOS-LAFS fermented by LAB BCRC13076 and/or BCRC14068 are shown in Table 5. The $\mathrm{H}_{2} \mathrm{O}_{2}$ scavenging capacity of the $24 \mathrm{LAB}$ fermentation products was found to be in the range of $37.3 \pm 0.9$ (Comb-GelSwPS-LAFP) to $76.0 \pm 2.0$ (14068-Mon-SwOS-LAFP), and their chelating capacity on ferrous ions of SwOS-LAFPs were better than SwPS-LAFPs for the same seaweed type. In addition, when comparing SwPS-LAFP and SwOS-LAFP which were fermented by LAB-BCRC13076, LAB-BCRC14068, or LAB-Comb, the results were as follows. (i) 13076-Por-SwOSLAFP was 1.1-fold higher than 13076-Por-SwPS-LAFP; (ii) 14068-Mon-SwOS-LAFP was 1.4-fold higher than 14068Mon-SwPS-LAFP; and (iii) Comb-Gel-SwOS-LAFP was 1.6 fold higher than Comb-Gel-SwPS-LAFP, respectively. The hydroxyl radicals scavenging capacity (\%) of (A) 12 SwPSLAFP which is derived from SwPS-LAFS or (B) 12 SwOS- 
Table 5. Hydrogen peroxide scavenging effect (\%) of (A) 12 SwPS-LAFP which is derived from SwPS-LAFS or (B) 12 SwOS-LAFP which is derived from SwOS-LAFS fermented with LAB BCRC13076 and/or BCRC14068.

\begin{tabular}{c|c|cccc}
\hline \multirow{2}{*}{ Strain } & \multirow{2}{*}{ Fermentation product } & \multicolumn{4}{|c}{ Scavenging effect (\%) } \\
\cline { 3 - 5 } & SwPS-LAFP** & $62.3 \pm 0.2^{\mathrm{c}[\mathrm{B}]}$ & $56.2 \pm 1.0^{\mathrm{d}[\mathrm{D}]}$ & $66.4 \pm 0.4^{\mathrm{c}[\mathrm{A}]}$ & $57.9 \pm 0.1^{\mathrm{d}[\mathrm{C}]}$ \\
\multirow{2}{*}{13076} & SwOS-LAFP & $68.5 \pm 0.2^{\mathrm{a}[\mathrm{B}]}$ & $63.8 \pm 0.6^{\mathrm{a}[\mathrm{D}]}$ & $69.6 \pm 0.1^{\mathrm{b}[\mathrm{A}]}$ & $65.8 \pm 0.6^{\mathrm{c}[\mathrm{C}]}$ \\
& & $57.2 \pm 0.9^{\mathrm{e}[\mathrm{B}]}$ & $57.1 \pm 0.1^{\mathrm{cd}[\mathrm{B}]}$ & $55.7 \pm 0.4^{\mathrm{d}[\mathrm{C}]}$ & $67.5 \pm 0.5^{\mathrm{b}[\mathrm{A}]}$ \\
& SwPS-LAFP & $54.9 \pm 0.2^{\mathrm{b}[\mathrm{C}]}$ & $60.7 \pm 1.3^{\mathrm{b}[\mathrm{D}]}$ & $76.0 \pm 2.0^{\mathrm{a}[\mathrm{A}]}$ & $72.3 \pm 0.6^{\mathrm{a}[\mathrm{B}]}$ \\
& SwOS-LAFP & $37.3 \pm 0.9^{\mathrm{f}[\mathrm{D}]}$ & $46.7 \pm 0.7^{\mathrm{e}[\mathrm{B}]}$ & $50.9 \pm 0.3^{\mathrm{e}[\mathrm{A}]}$ & $45.0 \pm 1.0^{\mathrm{e}[\mathrm{C}]}$ \\
& SwPS-LAFP & $50.5 \pm 0.3^{\mathrm{d}[\mathrm{B}]}$ & $57.8 \pm 0.3^{\mathrm{c}[\mathrm{C}]}$ & $68.7 \pm 0.5^{\mathrm{b}[\mathrm{A}]}$ & $57.9 \pm 0.4^{\mathrm{d}[\mathrm{C}]}$ \\
\hline
\end{tabular}

* Data are mean values of triplicate determinations \pm standard deviation. Different superscript small letters in the same column (vertical comparison) or capital letters in the same row (horizontal comparison) of brackets indicate significantly different values $(p<0.05)$.

** SwPS-LAFP, seaweed polysaccharide LAB fermentation product; SwOS-LAFP, seaweed oligosaccharide LAB fermentation product.

*** Gel, Gra, Mon, and Por represent SwPSExt are derived from Gelidium sp., Gracilaria sp., Mon. nitidum, and Por. dentate, respectively.

Table 6. Hydroxyl radicals scavenging effect (\%) of (A) 12 SwPS-LAFP which is derived from SwPS-LAFS or (B) 12 SwOS-LAFP derived from SwOS-LAFS fermented with LAB BCRC13076 and/or BCRC14068.

\begin{tabular}{c|c|cccc}
\hline \multirow{2}{*}{ Strain } & Fermentation product & \multicolumn{4}{|c}{ Scavenging effect (\%) } \\
\cline { 3 - 5 } 13076 & SwPS-LAFP** & Gel*** & - & Gra & Mon \\
& SwOS-LAFP & - & - & - & $25.6 \pm 4.4$ \\
& SwPS-LAFP & - & - & - & - \\
\multirow{2}{*}{14068} & SwOS-LAFP & - & - & - & - \\
& SwPS-LAFP & - & - & - & - \\
& SwOS-LAFP & - & - & $18.2 \pm 12.0$ & - \\
\hline
\end{tabular}

* Data are mean values of triplicate determinations \pm standard deviation. Different superscript small letters in the same column (vertical comparison) or capital letters in the same row (horizontal comparison) of brackets indicate significantly different values $(p<0.05)$.

** SwPS-LAFP, seaweed polysaccharide LAB fermentation product; SwOS-LAFP, seaweed oligosaccharide LAB fermentation product.

*** Gel, Gra, Mon, and Por represent SwPSExt are derived from Gelidium sp., Gracilaria sp., Mon. nitidum, and Por. dentate, respectively.

LAFP which is derived from SwOS-LAFS fermented by LAB BCRC13076 and/or BCRC14068 are shown in Table 6. The hydroxyl radicals scavenging capacity, except for 13076-PorSwOS-LAFP and Comb-Mon-SwOS-LAFP was $25.6 \pm 4.4$ and 18.2 \pm 12.0 , the other 22 LAB fermentation products had no hydroxyl radica.

Lin and Yen [27] demonstrated that Lb. delbrueckii ssp. bulgaricus $\mathrm{Lb}$ possesses the highest hydroxyl radical scavenging ability at $234 \mathrm{mM}$, and Strep. thermophilus $\mathrm{MC}$ and 821 and $L b$. delbrueckii ssp. bulgaricus 448 and 449 scavenged the most hydrogen peroxide at approximately $50 \mathrm{mM}$ in 11 tested LAB strains. Sakanaka et al. [45] reported that peptides hydrolysates from casein calcium showed hydroxyl radical-scavenging activity, and that this activity increased with the increase in concentration of casein calcium peptides. A $0.5 \%$ concentration of casein calcium peptides exhibited $78.4 \%$ scavenging activity. Hence, the peptides derived from beef extract and yeast extract proteins might also contribute to the scavenging capacity of SwPS-LAFPs or SwOS-LAFPs upon hydrogen peroxide.
In our previously study [57], we described that seaweed oligosaccharide solution could be fermented by LAB, and that probably two different strategies could be used to metabolize lactose or galactose depending on their mode of transport, either via the phosphenolpyruvate-dependent phosphotransferase system (PEP-PTS) or via a permease system. LAB has a complex proteolytic system that together with other proteolytic enzymes convert proteins into peptides, and increasing with LAB fermentation time [7]. Beef extract and yeast extract as the nitrogen source also promote lactic acid fermentation. These fermentation conditions could produce many metabolism products such as peptide hydrolysates that contribute antioxidative properties of SwPS-LAFPs or SwOSLAFPs. Therefore, proteins in SwPS-LAFPs or SwOS-LAFPs provide antioxidative abilities and have a chelating effect on ferrous ions. Moreover, peptide hydrolysates in SwPS-LAFPs or SwOS-LAFPs supply antioxidative abilities of reducing power, antioxidative abilities of inhibition to the hemoglobincatalyzed peroxidation of linoleic acid, and $\mathrm{H}_{2} \mathrm{O}_{2}$ scavenging capacity. Therefore peptides and proteins contribute to the 
mainly antioxidative capability of lactic acid fermentation products.

\section{ACKNOWLEDGMENTS}

The authors are grateful to the National Science Council, Taiwan, R.O.C. for the financial support received for this work (Grant No. NSC 92-2313-B-019-021).

\section{REFERENCES}

1. Ahn, C.-B., Jeon, Y.-J., Kang, D.-S., Shin, T.-S., and Jung, B.-M., "Free radical scavenging activity of enzymatic extracts from a brown seaweed Scytosiphon lomentaria by electron spin resonance spectrometry," Food Research International, Vol. 37, pp. 253-258 (2004).

2. Akhileshwar, V., Patel, S. P., and Katyare, S. S., "Diabetic cardiomyopathy and reactive oxygen species (ROS) related parameters in male and female rats: A comparative study," Indian Journal of Clinical Biochemistry, Vol. 22, pp. 84-90 (2007).

3. Al-Omar, M. A., Beedham, C., and Alsarra, I. A., "Pathological roles of reactive oxygen species and their defence mechanisms," Saudi Pharmaceutical Journal, Vol. 12, pp. 1-18 (2004).

4. Alkan, M., Yüksek, H., Gürsoy-Kol, Ö., and Calapoğlu, M., "Synthesis, acidity and antioxidant properties of some novel 3,4-disubstituted-4,5dihydro-1h-1,2,4-triazol-5-one derivatives," Molecules, Vol. 13, pp. 107 121 (2008).

5. Amanatidou, A., Smid, E. J., Bennik, M. H. J., and Gorris, L. G. M. "Antioxidative properties of Lactobacillus sake upon exposure to elevated oxygen concentrations," FEMS Microbiology Letters, Vol. 203, pp. 87-94 (2001).

6. Amaresan, M. S., "Cardiovascular disease in chronic kidney disease," The Indian Society of Nephrology, Vol. 15, pp. 1-7 (2005).

7. Àvila, M., Garde, S., Gaya, P., Medina, M., and Nuñez, M., "Effect of high-pressure treatment and a bacteriocin-producing lactic culture on the proteolysis, texture, and taste of hispánico cheese," Journal of Dairy Science, Vol. 89, pp. 2882-2893 (2006).

8. Babu, P. A., Suneetha, G., Boddepalli, R., Lakshmi, V. V., Rani, T. S., Babu, Y. R., and Srinivas, K., "A database of 389 medicinal plants for diabetes," Bioinformation, Vol. 1, pp. 130-131 (2006).

9. Benkeblia, N., "Free-radical scavenging capacity and antioxidant properties of some selected onions (Allium cepa L.) and garlic (Allium sativum L.) extracts," Brazilian Archives of Biology and Technology, Vol. 48, pp. 753-759 (2005).

10. Cadenas, E. and Davies, K. J., "Mitochondrial free radical generation, oxidative stress, and aging," Free Radical Biology and Medicine, Vol. 29, pp. 222-230 (2000).

11. Cao, Q., Wei, L.-R., Lu, L.-L., Zhao, C.-L., Zhao, H.-Y., and Yang, H., "Astrocytes protect MN9D neuronal cells against rotenone-induced oxidative stress by a glutathione-dependent mechanism," Acta Physiologica Sinica, Vol. 59, pp. 253-259 (2007).

12. Carroll, I. M., Andrus, J. M., Bruno-Barcena, J. M., Klaenhammer, T. R., Hassan, H. M., and Threadgill, D. S., "The anti-inflammatory properties of Lactobacillus gasseri expressing manganese superoxide dismutase (mnsod) using the interleukin 10-deficient mouse model of colitis,' American Journal of Physiology. Gastrointestinal and Liver Physiology, Vol. 293, pp. G729-G738 (2007).

13. Champagne, C., Gardner, N. J., and Roy, D., "Challenges in the addition of probiotic cultures to foods," Critical Reviews in Food Science and Nutrition, Vol. 45, pp. 61-84 (2005).

14. Cirelli, C., "Sleep disruption, oxidative stress, and aging: New insights from fruit flies," Proceedings of the National Academy of Sciences of the United States of America, Vol. 103, pp. 13901-13902 (2007).

15. Decker, E., "The role of phenolics, conjugated linoleic acid, carnosine, and pyroquinoline quinine as nonessential dietary antioxidants," Nutri- tion Reviews, Vol. 53, pp. 49-58 (1995).

16. de Felice, F. G., Velasco, P. T., Lambert, M. P., Viola, K., Fernandez, S. J., Ferreira, S. T., and Klein, W. L., “A $\beta$ oligomers induce neuronal oxidative stress through an N-methyl-D-aspartate receptor-dependent mechanism that is blocked by the Alzheimer drug memantine," The Journal of Biological Chemistry, Vol. 282, pp. 11590-11601 (2007).

17. Echeverri, D., Montes, F., Buitrago, L., Delgadillo, A., Beltrán, M., and Salgado, A., "Effective microorganisms (EM-X): In vitro action on aorta of hypercholesterolemic rabbits," Revista Colombiana de Cardiología, Vol. 14, pp. 123-132 (2007).

18. Faddah, L. M., Al-Rehany, M. A., Abdel-Hamid, N. M., and Bakeet, A. A., "Oxidative stress, lipid profile and liver functions in average Egyptian long term depo medroxy progesterone acetate (DMPA) users," Molecules, Vol. 10, pp. 1145-1152 (2005)

19. Fallarero, A., Loikkanen, J. J., Männistö, P. T., Castañeda, O., and Vidal, A., "Effects of aqueous extracts of Halimeda incrassata (Ellis) Lamouroux and Bryothamnion triquetrum (S. G. Gmelim) Howe on hydrogen peroxide and methyl mercuryinduced oxidative stress in GT1-7 mouse hypothalamic immortalized cells," Phytomedicine, Vol. 10, pp. 39-47 (2003).

20. Fernándesi, L. and Steelel, J. L., "Glutathione content of lactic acid bacteria,” Journal of Dairy Science, Vol. 76, pp. 1233-1242 (1993).

21. Halliwell, B., Gutteridge, H. M. C., and Aruoma, O. I., "The deoxyribose method: A simple "test-tube" assay for determination of rate constants for reactions of hydroxyl radicals," Analytical Biochemistry, Vol. 165, pp 215-219 (1987).

22. Huang, G.-J., Chen, H.-J., Chang, Y.-S., Sheu, M.-J., and Lin, Y.-H., "Recombinant sporamin and its synthesized peptides with antioxidant activities in vitro," Botanical Studies, Vol. 48, pp. 133-140 (2007).

23. Ismail, A. and Hong, T. S., "Antioxidant activity of selected commercial seaweeds," Malaysia Journal of Nutrition, Vol. 8, pp. 167-177 (2002).

24. Kevers, C., Falkowski, M., Tabart, J., Defraigne, J.-O., Dommes, J., and Pincemail, J., "Evolution of antioxidant capacity during storage of selected fruits and vegetables," Journal of Agricultural and Food Chemistry, Vol. 55, pp. 8596-8603 (2007).

25. Konings, W. N., Lolkema, J. S., Bolhuis, H., van Veen, H. W., Poolman, B., and Driessen, A. J. M., "The role of transport processes in survival of lactic acid bacteria, energy transduction and multidrug resistance," Antonie van Leeuwenhoek, Vol. 71, pp. 117-128 (1997).

26. Kuo, J.-M., Yeh, D.-B., and Pan, B.-S., "Rapid photometric assay evaluating antioxidative activity in edible plant material," Journal of Agricultural and Food Chemistry, Vol. 47, pp. 3206-3209 (1999).

27. Lin, M.-Y. and Yen, C.-L., "Reactive oxygen species and lipid peroxidation product-scavenging ability of yogurt organisms," Journal of Dairy Science, Vol. 82, pp. 1629-1634 (1999).

28. Liu, J.-R., Chen, M.-J., and Lin, C.-W., "Antimutagenic and antioxidant properties of milk-kefir and soymilk-kefir," Journal of Agricultural and Food Chemistry, Vol. 53, pp. 2467-2474 (2005).

29. Mao, L.-C., Pan, X., Que, F., and Fang, X.-H., “Antioxidant properties of water and ethanol extracts from hot air-dried and freeze-dried daylily flowers," European Food Research and Technology, Vol. 22, pp. 236-241 (2006).

30. Mapp, P. I., Grootveld, M. C., and Blake, D. R., "Hypoxia, oxidative stress and rheumatoid arthritis," British Medical Bulletin, Vol. 51, pp. 419-436 (1995).

31. Mayr, M., Zhang, J., Greene, A. S., Gutterman, D., Perloff, J., and Ping, P., "Proteomics-based development of biomarkers in cardiovascular disease," Molecular and Cellular Proteomics, Vol. 5, pp. 1853-1864 (2006).

32. McCue, P. P. and Shetty, K., "Role of carbohydrate-cleaving enzymes in phenolic antioxidant mobilization from whole soybean fermented with Rhizopus oligosporus," Food Biotechnology, Vol. 17, pp. 27-37 (2003).

33. McCue, P. P. and Shetty, K., "Phenolic antioxidant mobilization during yogurt production from soymilk using kefir cultures," Process Biochemistry, Vol. 40, pp. 1791-1797 (2005).

34. Mistry, V. V., Kosikowski, J. F. V., and Bellamy, W. D., "Improvement of lactic acid production in ultrafiltered milk by the addition of nutrients," Journal of Dairy Science, Vol. 70, pp. 2220-2225 (1987). 
35. Naidu, M. S. K., Suryakar, A. N., Swami, S. C., Katkam, R. V., and Kumbar, K. M., "Oxidative stress and antioxidant status in cervical cancer patients," Indian Journal of Clinical Biochemistry, Vol. 22, pp. 140-144 (2007).

36. Pena-Ramos, E. A. and Xiong, Y. L., "Antioxidative activity of whey protein hydrolysates in a liposomal system," Journal of Dairy Science, Vol. 84, pp. 2577-2583 (2001).

37. Peran, L., Camuesco, D., Comalada, M., Nieto, A., Concha, A., Adrio, J. L., Olivares, M., Xaus, J., Zarzuelo, A., and Galvez, J., “Lactobacillus fermentum, a probiotic capable to release glutathione, prevents colonic inflammation in the TNBS model of rat colitis," International Journal of Colorectal Disease, Vol. 21, pp. 737-746 (2006).

38. Phadtare, S., "Recent developments in bacterial cold-shock response," Current Issues in Molecular Biology, Vol. 6, pp. 125-136 (2004).

39. Read, R. S. D., "Macronutrient innovations and their educational implications: Proteins, peptides and amino acids," Asia Pacific Journal of Clinical Nutrition, Vol. 11, pp. S174-S183 (2002).

40. Rivero, F., Fallarero, A., Castaňeda, O., Dajas, F., Manta, E., Areces, F. Filho, J. M., and Vidal, A., "Antioxidant activity in vivo and in vitro of Halimeda incrassata aqueous extracts," Ciência e Tecnologia de Alimentos, Vol. 23, pp. 256-263 (2003).

41. Robards, K., Prenzler, P. D., Tucker, G., Swatsitang, P., and Glover, W., "Phenolic compounds and their role in oxidative processes in fruits," Food Chemistry, Vol. 66, pp. 401-436 (1999).

42. Rohn, S., Rawel, H., and Kroll, J.-R., "Antioxidant activity of protein-bound quercetin," Journal of Agricultural and Food Chemistry, Vol. 52, pp. 4725-4729 (2004).

43. Rupérez, P., Ahrazem, O., and Leal, J. A., "Potential antioxidant capacity of sulfated polysaccharides from the edible marine brown seaweed Fucus vesiculosus," Journal of Agricultural and Food Chemistry, Vol. 50, pp. 840-845 (2002).

44. Saide, J. A. O. and Gillil, E., "Antioxidative activity of lactobacilli measured by oxygen radical absorbance capacity," Journal of Dairy Science, Vol. 88, pp. 1352-1357 (2005).

45. Sakanaka, S., Tachibana, Y., Ishihara, N., and Juneja, L. R., "Antioxidant properties of casein calaium peptides and their effects on lipid oxidation in beef homogenates," Journal of Agricultural and Food Chemistry, Vol. 53, pp. 464-468 (2005).

46. SAS Inst., "User's Guide," Release 8.0 ed. SAS Institution, Cary, N. C. (1997).

47. Starnes, J. W., Barnes, B. D., and Olsen, M. E., "Exercise training decreases reactive oxygen species generation but does not attenuate $\mathrm{Ca}^{2+}$ induced dysfunction in rat heart mitochondria," Journal of Applied Phycology, Vol. 102, pp. 1793-1798 (2007).

48. Tandon, V. R., Sharma, S., Mahajan, A., and Bardi, G. H., "Oxidative stress: A novel strategy in cancer treatment," JK Science, Vol. 7, pp. 1-3 (2005).

49. Terahara, M., Takeama, S., and Kurmoto, N., "Prevention by lactic acid bacteria of the oxidation of human LDL," Bioscience, Biotechnology, and Biochemistry, Vol. 65, pp. 1864-1868 (2001).

50. Toyokuni, S., "Iron and carcinogenesis: From Fenton reaction to target genes," Redox Report, Vol. 7, pp. 189-197 (2002)

51. Tutour, B. L., "Antioxidative activities of algal extracts, synergistic effect with vitamin E," Phytochemistry, Vol. 29, pp. 3759-3765 (1990).

52. Vaisi-Raygani, A., Rahimi, Z., Zahraie, M., Noroozian, M., and Pourmotabbed, A., "Enzymatic and non-enzymatic antioxidantdefense in Alzheimer's disease,” Acta Medica Iranica, Vol. 45, pp. 271-276 (2007).

53. Wong, P. Y. Y. and Kitts, D. D., "Chemistry of buttermilk solid antioxidant activity," Journal of Dairy Science, Vol. 86, pp. 1541-1547 (2003).

54. Wu, J.-T. and Wu, L.-L., "Chronic systemic inflammation leading eventually to myocardial infarction, stroke, COPD, renal failure and cancer is induced by multiple risk factors," Journal of Biomedical and Laboratory Sciences, Vol. 19, pp. 1-5 (2007).

55. Wu, S.-C. and Pan, C.-L., "Preparation of algal-oligosaccharide mixtures by bacterial agarases and their antioxidative properties," Fisheries Science, Vol. 70, pp. 1164-1173 (2004).

56. Wu, S.-C., Wang, F.-J., and Pan, C.-L., "Growth and survival of Streptococcus faecalis and Lactobacillus rhamnosus during agar oligosaccharides fermentation and storage," Journal of the Fisheries Society of Taiwan, Vol. 32, pp. 239-251 (2005a).

57. Wu, S.-C., Wang, F.-J., and Pan, C.-L., "Growth and survival of lactic acid acteria during the fermentation and storage of seaweed oligosaccharides solution," Journal of Marine Science and Technology, Vol. 15, pp. 104-114 (2007).

58. Wu, S.-C., Wen, T.-N., and Pan, C.-L., "The antioxidative properties of algal-oligosaccharide-lysates hydrolyzed by two bacterial agarases," Fisheries Science, Vol. 71, pp. 1149-1159 (2005b).

59. Yamaguchi, T., Takamura, H., Matoba, T., and Terao, J., "HPLC method for evaluation of the free radical-scavenging activity of foods by using 1,1,-diphenyl-2-picrylhydrazyl," Bioscience, Biotechnology, and Biochemistry, Vol. 62, pp. 1201-1204 (1998).

60. Yen, G.-C., Duh, P.-D., and Tsai, H.-L., "Antioxidant and pro-oxidant properties of ascorbic acid and gallic acid," Food Chemistry, Vol. 79, pp. 307-313 (2002).

61. Yuan, H., Zheng, J.-C., Liu, P., Zhang, S.-F., Xu, J.-Y., and Bai, L.-M., "Pathogenesis of Parkinson's disease: Oxidative stress, environmental impact factors and inflammatory processes," Neuroscience Bulletin, Vol. 23, pp. 125-130 (2007).

62. Zommara, M., Tachibana, N., Sakono, M., Suzuki, Y., Oda, T., Hashiba, H., and Imaizumi, K., "Whey from cultured skim milk decreases serum cholesterol and increases antioxidant enzymes in liver and red blood cells in rats," Nutrition Research, Vol. 16, pp. 293-302 (1996).

63. Zubia, M., Robledo, D., and Freile-Pelegrin, Y., "Antioxidant activities in tropical marine macroalgae from the Yucatan Peninsula, Mexico," Journal of Applied Phycology, Vol. 19, pp. 449-458 (2007). 